\title{
POPULATION DYNAMICS OF ATTALEA EXCELSA (ARECACEAE) IN FLOODPLAIN FOREST OF THE AMAZONIAN ESTUARY
}

\author{
Dantas $\mathrm{AR}^{1, *}$, Lira-Guedes $\mathrm{AC}^{2}$, Guedes $\mathrm{MC}^{2}$, Piedade $\mathrm{MTF}^{1} \&{\text { Batista } \mathrm{APB}^{3}}^{3}$ \\ ${ }^{1}$ National Institute for Amazonian Research, André Araújo 2936, Petrópolis, 69067-375, Manaus, Brazil \\ ${ }^{2}$ Brazilian Agricultural Research Corporation, Rodovia Juscelino Kubitscheck 2600, 68903-419, Macapá, Brazil \\ ${ }^{3}$ Federal Institute of Education, Science and Technology of Amazonas, São Gabriel da Cachoeira, Centro, 69750-970, São \\ Gabriel da Cachoeira, Brazil \\ *adelson.dantas@yahoo.com.br
}

Submitted December 2018; accepted December 2019

\begin{abstract}
Attalea excelsa (urucurizeiro) is a dominant palm of the estuarine floodplains, with great potential for nontimber management. This study evaluated the population dynamics of urucurizeiro and the factors that contribute to colonising of this species in a flooded environment. Individuals with base height circumference $\geq 30 \mathrm{~cm}$ in 2011 and 2014 were measured in 55.95 ha of floodplain forest in southern Amapá, Brazil. The parameters of population dynamics (mortality, recruitment and growth) in high and low floodplain environments were determined. Ripley's K function was used to analyse the spatial distribution. Population density in 2011 was 3.99 individual $\mathrm{ha}^{-1}$, and in 2014 the density increased to 4.09 individual ha $\mathrm{a}^{-1}$. Mortality rate was zero and the recruitment rate was $1.05 \%$ year $^{-1}$. Basal area in 2011 was $0.49 \mathrm{~m}^{2} \mathrm{ha}^{-1}$ and in 2014, it reached $0.72 \mathrm{~m}^{2} \mathrm{ha}^{-1}$. Diameter growth rate was $5.32 \mathrm{~cm}_{\text {year }}$. The population presented an aggregate distribution pattern. Structural differences in diameter $(\mathrm{F}=9.15, \mathrm{p}=0.003)$ and basal area $(\mathrm{F}=10.7, \mathrm{p}=0.001)$ were evident between high and low floodplain forests. The increase in diameter was higher in low floodplain $\left(3.98 \mathrm{~cm} \mathrm{year}^{-1}\right)$ compared with high floodplain $\left(1.35 \mathrm{~cm}_{\text {year }}{ }^{-1}\right)$. The patterns shown by $A$. excelsa are reflections of its high adaptation to the daily flooded environment.
\end{abstract}

Keywords: Urucurizeiro, flood gradient, topography, aggregate distribution, mortality, palm, Ripley's K function

\section{INTRODUCTION}

The Arecaceae family has a wide geographical distribution, occurring in all tropical and subtropical regions (Eiserhardt et al. 2011). In the Amazon forests 39 genus of palm trees have been documented, with 34 of them occurring in the western region, 22 in the central region and 20 in the eastern region (Kahn \& Granville 1992). This family has great prominence in the forests of the Amazon basin due to the richness and floristic diversity of the area (Wittmann et al. 2006).

Palm trees constitute one of the most ubiquitous vegetable groups in the Amazon, performing important ecological, social and economic functions (Smith 2015). Different parts of these palms are useful in construction, food, handicrafts, religious rituals and alternative therapies (Martins et al. 2014). The Attalea genus is one of the most conspicuous groups of neotropical palms. This genus has a wide geographical distribution and can be found in Mexico, Paraguay, Brazil, in the Caribbean countries, and in the Andes at altitudes of 1200 to $1600 \mathrm{~m}$ (Pintaud 2014). Attalea has great ecological variation and high adaptive potential to colonise new areas (Freitas et al. 2016).

Attalea excelsa (urucurizeiro) is one of the most dominant palm species in the floodplains of the Amazonian estuary (Carim et al. 2016). Also popularly known as urucuri, $A$. excelsa has a wide range of uses including fruit, seed, straw (dried leaves), folk medicine and handicrafts (Smith 2015). There are only a few studies addressing the ecology of non-timber plant species in Amazon rainforest floodplains (Jardim \& Mota 2007, Dantas et al. 2016), although certain species like A. excelsa presents great economic potential.

Population dynamics studies are important to evaluate the factors related to successful colonisation of the plant in its habitat. The main factors for the diversification and establishment of palm communities are climate, topography, 
soil and hydrology (Balslev et al. 2011). Seed dispersal process also exerts great influence on the structure of plant communities (Nathan \& Muller-Landau 2000), especially in demographic parameters such as natality and mortality rates, and in subsequent processes of plant predation, competition and reproduction. Particularly in Amazonian floodplain forests, the annual or periodic flood pulse exerts great control on the population dynamics of plants, since it acts directly in the processes of dispersion, reproduction (Wittmann et al. 2010) and soil sedimentation (Wittmann et al. 2004).

For management and conservation, understanding the main interactive processes between species and their habitats is fundamental, as these processes regulate population parameters such as natality rate, growth rate and mortality. For this reason, the objective of this study was to determine the demographic parameters of an Attalea excelsa population, and evaluate the factors that contribute to colonisation of the species in the estuarine floodplain forest in southern Amapá.

\section{MATERIALS AND METHODS}

\section{Study area}

The present study was developed at the Mazagão Experimental Field (CEM) site, belonging to the Amapá Brazilian Agricultural Research Corporation. CEM has 55.95 ha of floodplain forest, located in the municipality of Mazagão, in the south of Amapá State $\left(00^{\circ} 06^{\prime} \mathrm{S}, 51^{\circ} 16^{\prime} \mathrm{W}\right)$
(Dantas et al. 2014). The CEM floodplain forest is quite heterogeneous due to the flood dynamics and slope of the terrain, forming an environment of high floodplain, low floodplain and lowlands. The low floodplain soil is submerged daily by the river, with water reaching up to $60 \mathrm{~cm}$ height of the tree trunks. The high floodplain presents a slope of 3 to $3.5 \mathrm{~m}$ in height, hindering the entrance of the daily tide. However, the soil is submerged in March because the high tide of the Amazon river in this period is influenced by the high precipitation of the Amazonian winter and the full moon. There is a more concave part in the center of the area, where water is dammed almost all year round (Dantas et al. 2014). The flooding cycle of the area is polymodal, characterised by two daily flood cycles influenced by the ocean tide, with an average amplitude of the flood pulse being $1.32 \mathrm{~m}$ (Junk et al. 2014).

The climatic type of the region is the Am, characteristic of a rainy tropical climate (Alvares et al. 2014). The annual average temperature is $27^{\circ} \mathrm{C}$ and the average daily range is less than $3{ }^{\circ} \mathrm{C}$ in all months. The average annual precipitation is $2550 \mathrm{~mm}$, with rainy season from January to May. The soils of the area are classified as typical Melanic Gleysols Ta Eutrophic, with predominance of silt. Both the sediment and the soil are formed by smectite, illite, kaolinite, goethite, anatase and quartz (Dantas et al. 2017).

The predominant vegetation is the dense alluvial ombrophilous forest (IBGE 2012), with a high frequency of palm trees and large trees of commercial value. Attalea excelsa (Figure 1a) is 10 to $20 \mathrm{~m}$ high and its BHD (base height diameter)

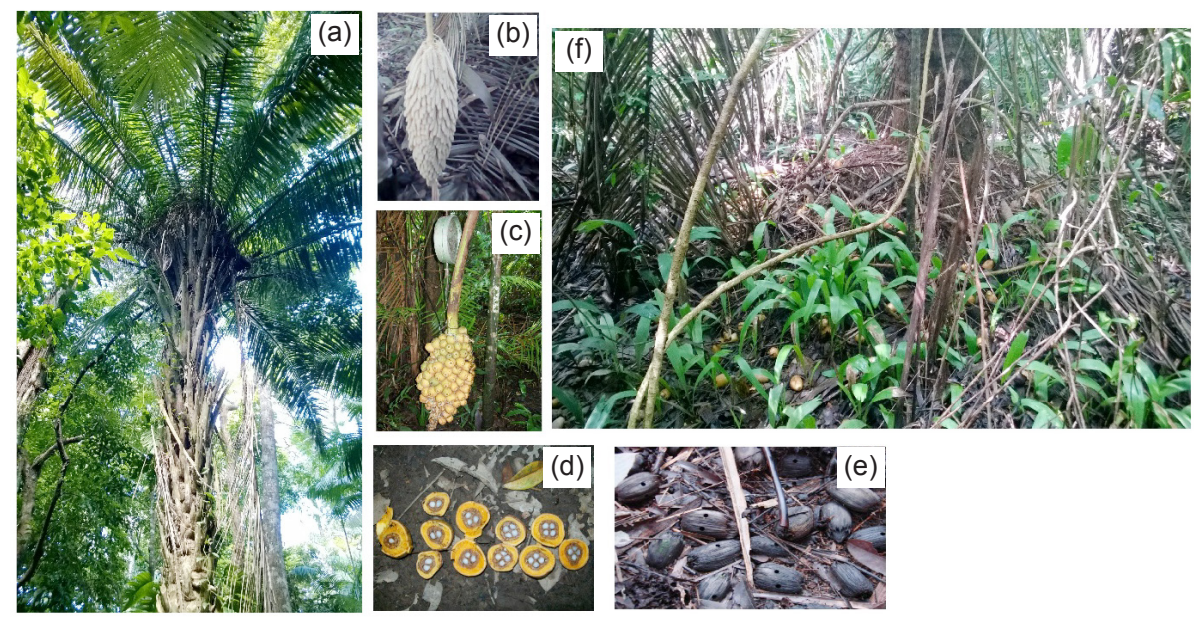

Figure 1 Attalea excelsa in the floodplain forest of the Mazagão Experimental Field, Amapá State: (a) adult individual with trunk covered by leaf sheath remains, (b) inflorescence; (c) infructescence, (d) cross-section of fruits showing almonds, (e) seeds bored by beetles; and (f) seedling bank of $A$. excelsa under a matrix palm 
can reach up to $86 \mathrm{~cm}$. In the CEM site, the species is frequently sharing the arboreal neighbourhood with Carapa guianensis, Pentaclethra macroloba, Calycophyllum spruceanum, Astrocaryum murumuru, Swartzia racemosa, Pterocarpus amazonicus and Mora paraensis.

\section{Sample data}

In 2011 and 2014, all the A. excelsa trees with base height circumference $(\mathrm{BHC}) \geq 30 \mathrm{~cm}$ were measured. The BHC was measured because the urucuzeiro stem had live leaf agglomerates or sheath remains at a height of $1.30 \mathrm{~m}$. The surveys were done in 12 transects perpendicularly installed at the main river, the 'furo do Mazagão' (tributary of the Amazon river), and parallel in the south-north direction with a $50 \mathrm{~m}$ distance between transects and varied transect length (339 to $770 \mathrm{~m}$ ) according to the sinuosity of the border of the area (Dantas et al. 2017).

During the first inventory (2011), data on BHC, height, geographic coordinates, presence or absence of termites, vines and reproductive structures (flowers or fruits) were obtained from the A. excelsa population. In 2014, the BHCs of individuals from the first inventory were remeasured, and those that were not measured in the first inventory because they did not meet the $\mathrm{BHC}$ inclusion criterion $\geq 30 \mathrm{~cm}$, were also measured and included in the sample (included individuals). Dead individuals were quantified in the 2014 inventory.

All inventoried individuals were numerically identified with zinc plates, besides being georeferenced with GPS Garmin model 60CSx, with errors between 3 and $4 \mathrm{~m}$, and a maximum of $6 \mathrm{~m}$ at the time close to noon when satellite signals were more difficult to capture (Dantas et al. 2017).

\section{Data analysis}

The BHC was converted to BHD. The following population parameters were calculated: mortality rate (M) (Sheil et al. 1995), recruitment rate (R) (Sheil et al. 2000), half-life $\left(\mathrm{T}_{0.5}\right)$, doubling time $\left(\mathrm{T}_{2}\right)$ (Korning \& Balslev 1994) and relative growth rate (RGR) (Shen et al. 2013), following the equations:

$$
\mathrm{M}=1-\left[1-\left(\frac{\mathrm{N}_{0}-\mathrm{N}_{1}}{\mathrm{~N}_{0}}\right)\right]^{\frac{1}{\mathrm{t}}}
$$

$$
\begin{aligned}
& \mathrm{R}=1-\left(\frac{1-\mathrm{N}_{\mathrm{r}}}{\mathrm{N}_{1}}\right)^{\frac{1}{\mathrm{t}}} \\
& \mathrm{T}_{0.5}=\left(\frac{\ln (0.5)}{0.01 \times \mathrm{M}}\right) \\
& \mathrm{T}_{2}=\left(\frac{\ln (2)}{0.01 \times \mathrm{R}}\right) \\
& \text { RGR }=\left(\frac{\log \left(\mathrm{BHD}_{1}\right)-\log \left(\mathrm{BHD}_{0}\right)}{\mathrm{t}}\right)
\end{aligned}
$$

where,

$\mathrm{M}$ is the annual mortality rate, $\mathrm{N}_{0}$ is the number of individuals from the first inventory, $\mathrm{N}_{1}$ is the total number of individuals surviving in the last inventory, $\mathrm{t}$ is the time between the first and second inventories, $\mathrm{R}$ is the annual recruitment rate, $\mathrm{N}_{\mathrm{r}}$ is the number of individuals entering the second inventory, $\mathrm{T}_{0.5}$ is the half-life parameter, $\mathrm{T}_{2}$ is the population doubling time; RGR is the relative growth rate, $\mathrm{BHD}_{0}$ is the diameter measured in the first inventory, and $\mathrm{BHD}_{1}$ is the diameter measured in the second inventory.

The individuals sampled were grouped into diameter classes according to the formula proposed by Sturges (1926), which suggests a reasonable number of classes that varies according to the number of occurrence and data extension:

$$
\mathrm{k}=1+3.3 \operatorname{In}(\mathrm{N})
$$

where,

$\mathrm{k}$ is the number of classes, $\mathrm{ln}$ is the natural logarithm and $\mathrm{N}$ is the total number of sampled individuals.

The spatial distribution pattern of population and productive matrices was determined by the univariate Ripley K function (Ripley 1981). The null hypothesis of this function considers complete spatial randomness, which means the process that generate spatial distribution pattern is random at any distance scale (Ripley 1981). The geographic coordinates of each individual, ' $x$ ' and ' $y$ ' coordinates in Universal Transverse of Marcator, were used to determine the spatial distribution pattern.

The $\mathrm{K}$ function quantifies the distance of a point from the neighbouring points by means of a distance vector (s) that rotates around the centre point in a $360^{\circ}$ radius, capturing all neighbouring points. The radius of distance $s$ is 
defined based on half the length of the smallest side of the study area to avoid estimation errors. In this way, the distance vector will not exceed the study area limits, avoiding errors in the distribution pattern estimates (Diggle 2003). The $\mathrm{s}$ radius used for this study ranged from 0 to $350 \mathrm{~m}$, which corresponded to approximately half the smaller side of the study area (Dantas et al. 2017). The complete spatial randomness null hypothesis was tested through 1000 Monte Carlo simulations to generate confidence envelopes at the significance level given by $\alpha=1 /(\mathrm{s}+1)$, where $\mathrm{s}$ is the distance vector. The values of the observed, maximum and minimum estimates are plotted on a graph as a function of distances.

The function $\mathrm{K}$ was transformed into the function $\mathrm{L}(\mathrm{h})$ for better visualisation of the results and to compare the estimation of the $\mathrm{K}$ function with the complete spatial randomness hypothesis. The graph generated with the transformed function $\mathrm{L}(\mathrm{h})$ facilitated visualising the deviations (packages of complete spatial randomness) in relation to the null hypothesis, whose abscissa axis represented the distance $\mathrm{s}$ (in $\mathrm{m}$ ), and the transformed function $\mathrm{L}(\mathrm{h})$ as the ordinates (Ripley 1981). In this type of analysis, the random pattern could be observed when the function $\mathrm{L}(\mathrm{h})$ assumed zero value, being among the complete spatial randomness confidence envelopes. The aggregate pattern could be observed when the $\mathrm{L}(\mathrm{h})$ function assumed positive values, with positioning above the complete spatial randomness packets. In contrast, the $\mathrm{L}(\mathrm{h})$ function took negative values in the regular pattern, below the complete spatial randomness packets.

Considering that the forest under study presented different flooding levels due to the lower elevation topographic dimension near the furo do Mazagão (westward) and higher topographic level in the opposite direction (towards the east), the influence of the flood gradient was verified with the parameters of $A$. excelsa population dynamics. For this, a Terrain Altimetric Digital Elevation Model (DEM) was obtained from the Geomorphometric Database of Brazil, from the National Institute for Space Research (INPE 2017) and analysed. The DEM image was processed using ArcGis v.10.1 Software (ArcMap). The individuals were divided between high and low floodplains, using the information of the altimetric map and field visual diagnosis.
Analysis of variance at $0.05 \%$ probability was applied to verify the structural differences of diameter and basal area and the diametric and basal area growth rates between high floodplain and low floodplain environments. The environments were treated as fixed effects (Klimas et al. 2007). All statistical analyses were performed using Program R version 3.1.0 (2014, http://www.r.project.org), and for the spatial distribution, the package Splancs ( $R$ package version 2.01-15) was used (Rowlingson \& Diggle 2013).

\section{RESULTS}

\section{Population dynamics}

In the first survey (2011), 223 A. excelsa trees were sampled, and in the second survey (2014), 229 individuals were registered, which corresponded to a population density of 3.99 and 4.09 individuals $\mathrm{ha}^{-1}$ respectively. Mortality rate of the population from 2011 to 2014 was zero and the recruitment rate was $1.05 \%$ year $^{-1}$ (six individuals incorporated). With zero mortality, it was not possible to estimate the population decline rate. If the recruitment rate of $1.05 \%$ year ${ }^{-1}$ is maintained, the population will double in size from 229 individuals to 458 in 66 years.

The population was structured in nine BHD size classes, with few individuals in the initial classes, and the majority concentrated in the central diameter classes, representing a normal distribution pattern (Figure 2). The lowest BHD found was $12 \mathrm{~cm}$ and the maximum, $86 \mathrm{~cm}$, and the population had a mean BHD of $42 \mathrm{~cm}^{-1}$. The classes that had the greatest increase in diameter (due to the migration between classes and the entry of individuals) were those that were in the range of $41.1-48.0 \mathrm{~cm}, 48.1-55.0 \mathrm{~cm}$ and $55.1-$ $62.0 \mathrm{~cm}$ (Table 1). The average relative population growth rate in diameter was $5.32 \mathrm{~cm}_{\text {year }}{ }^{-1}$.

Basal area of the population (Figure 3 ) showed an increase of $47 \%$ in the study period, from $0.49 \mathrm{~m}^{2} \mathrm{ha}^{-1}$ in the first survey to $0.72 \mathrm{~m}^{2} \mathrm{ha}^{-1}$ in the second. Individuals who were in the 41.1 to $62.0 \mathrm{~cm}$ diameter intervals had greater increases in basal area (Table 1). A total of 124 productive individuals were registered in the inventory of 2011, and these were used in analysing spatial distribution of productive matrices. Considering the 229 individuals in the 2014 inventory, the population presented an 

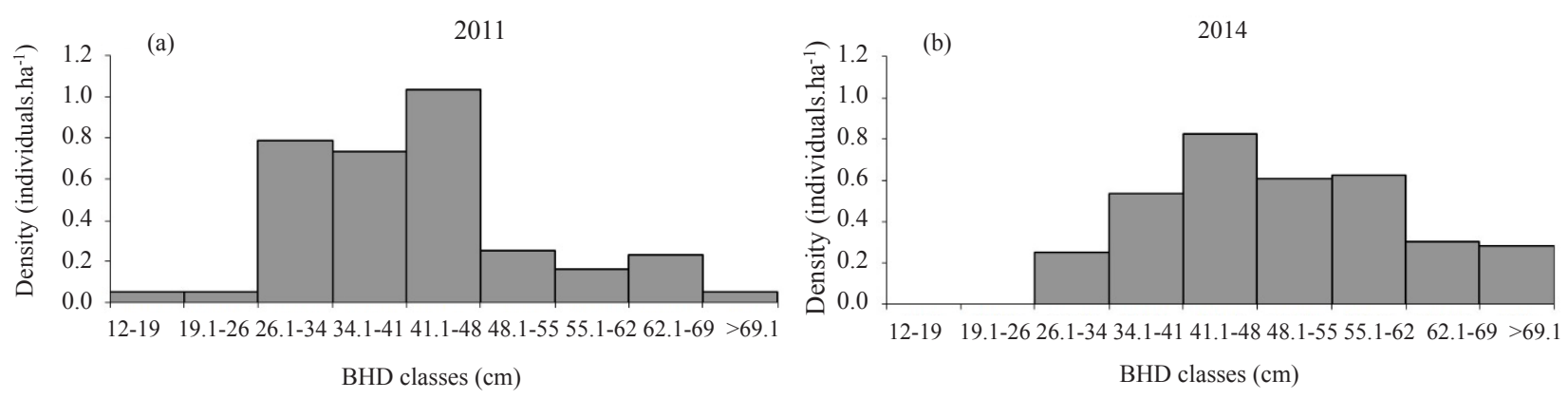

Figure 2 The population structure of A. excelsa in 2011 (a) and 2014 (b) in the Mazagão floodplain forest, south-east Amapá State, Brazil; BHD = base height diameter

Table 1 Relative growth rate (RGR) in base height diameter (BHD) and basal area in the interval of three years of monitoring the population dynamics of Attalea excelsa in the Mazagão floodplain forest, south-east Amapá State

\begin{tabular}{|c|c|c|}
\hline $\begin{array}{l}\text { BHD class } \\
\quad(\mathrm{cm})\end{array}$ & $\begin{array}{l}\text { RGR of BHD } \\
\left(\mathrm{cm} \text { year }^{-1}\right)\end{array}$ & $\begin{array}{l}\text { RGR of basal area } \\
\left(\mathrm{m}^{2} \mathrm{ha}^{-1} \text { year }^{-1}\right)\end{array}$ \\
\hline $12.0-19.0$ & 0.00 & 0.00 \\
\hline $19.1-26.0$ & 0.00 & 0.00 \\
\hline $26.1-34.0$ & 0.19 & 0.01 \\
\hline $34.1-41.0$ & 0.81 & 0.03 \\
\hline $41.1-48.0$ & 1.06 & 0.04 \\
\hline $48.1-55.0$ & 1.07 & 0.04 \\
\hline $55.1-62.0$ & 1.22 & 0.04 \\
\hline $62.1-69.0$ & 0.50 & 0.02 \\
\hline$>69.1$ & 0.48 & 0.02 \\
\hline Total & 5.33 & 0.20 \\
\hline
\end{tabular}
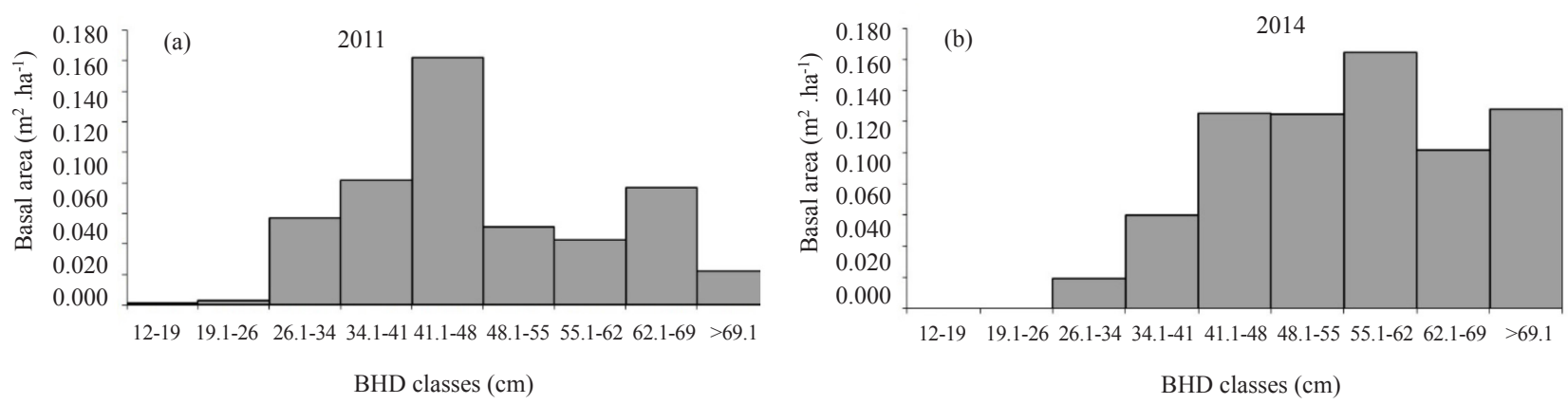

Figure 3 Basal area of a A. excelsa population in 2011 (a) and 2014 (b) in the Mazagão floodplain forest, south-east Amapá State; BHD = base height diameter

aggregated spatial distribution pattern, since the $\mathrm{L}(\mathrm{h})$ (continuous line) function was above the confidence envelopes (dashed lines), rejecting the null hypothesis of complete spatial, assuming an aggregate pattern at all distances scales (Figure 4a). This pattern was also observed for productive adults (Figure $4 \mathrm{~b}$ ).

\section{Dynamics of the individuals of the high and low floodplains}

The low floodplain presented a higher density of individuals compared with the high floodplain, while the species did not occur in the lowlands (Figure 5, Table 2). Increases in BHD and basal 

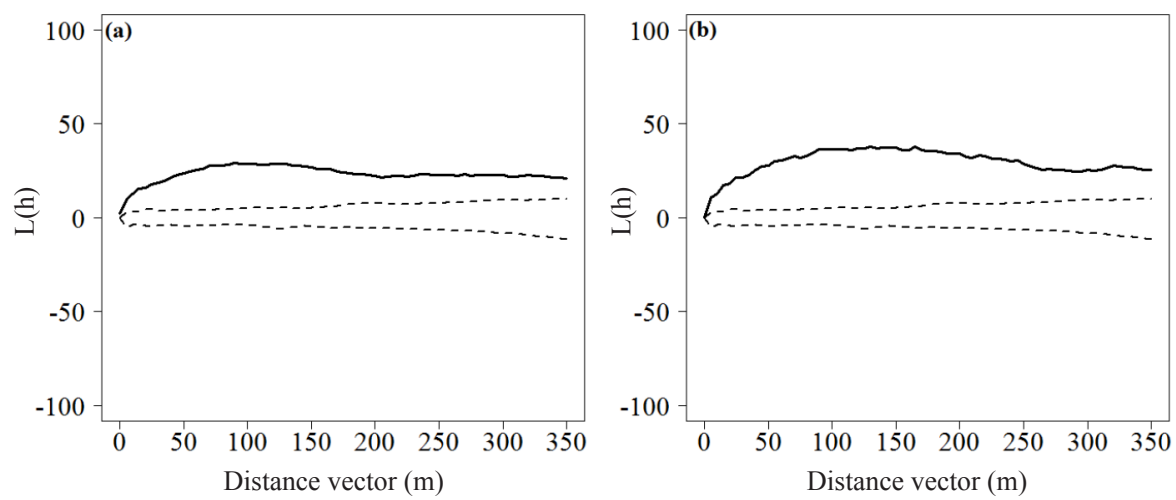

Figure 4 Spatial distribution of $A$. excelsa population (a) and productive individuals (b) in Mazagão floodplain forest, south-east Amapá State, Brazil

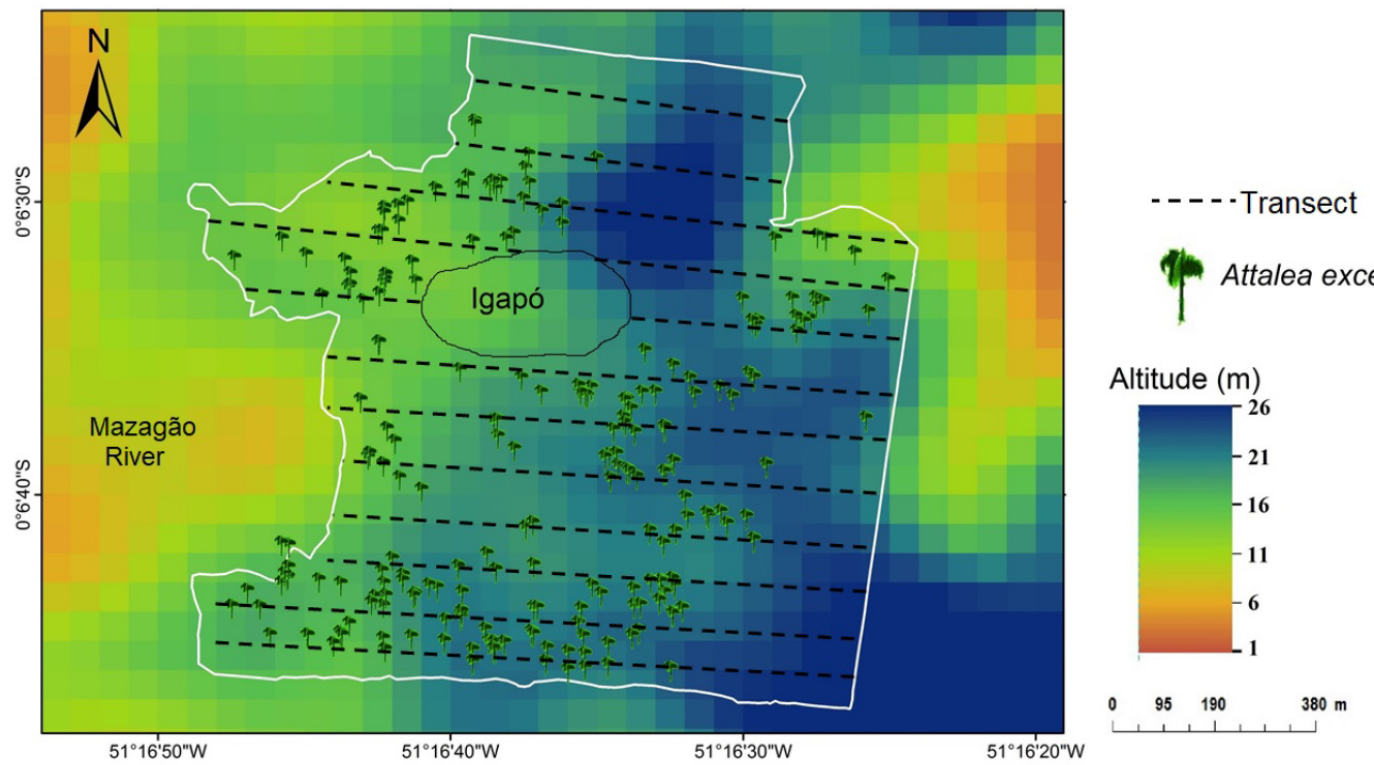

Figure 5 Distribution of A. excelsa individuals as a function of the flood gradient of Mazagão floodplain forest, south-east Amapá State

Table 2 Parameters of the dynamics of A. excelsa individuals in a highland and lowland environment in the Mazagão floodplain forest, south-east Amapá State

\begin{tabular}{|c|c|c|}
\hline \multirow[t]{2}{*}{ Population parameter } & \multicolumn{2}{|c|}{ Year } \\
\hline & 2011 & 2014 \\
\hline \multicolumn{3}{|l|}{ High floodplain } \\
\hline Density (individuals ha $\mathrm{ha}^{-1}$ ) & 0.70 & 0.70 \\
\hline Basal area $\left(\mathrm{m}^{2} \mathrm{ha}^{-1}\right)$ & 0.13 & 0.19 \\
\hline RGR of BHD (cm year $\left.{ }^{-1}\right)$ & - & 1.35 \\
\hline RGR of basal area $\left(\mathrm{m}^{2} \mathrm{ha}^{-1} \cdot \mathrm{year}^{-1}\right)$ & - & 0.05 \\
\hline \multicolumn{3}{|l|}{ Low floodplain } \\
\hline Density (individuals ha $\mathrm{ha}^{-1}$ ) & 2.66 & 2.73 \\
\hline Basal area $\left(\mathrm{m}^{2} \mathrm{ha}^{-1}\right)$ & 0.37 & 0.53 \\
\hline RGR of BHD (cm year $\left.{ }^{-1}\right)$ & - & 3.98 \\
\hline RGR of basal area $\left(\mathrm{m}^{2} \mathrm{ha}^{-1}\right.$ year $\left.{ }^{-1}\right)$ & - & 0.14 \\
\hline
\end{tabular}

$\mathrm{RGR}=$ relative growth rate; $\mathrm{BHD}=$ base height diameter 
area were higher in the low floodplain (Table 2), giving indications that individuals were well adapted to the daily flooded environment. The ANOVA test showed a structural difference in diameter $(\mathrm{df}=1, \mathrm{~F}=9.15, \mathrm{p}=0.003)$ and basal area $(\mathrm{df}=1, \mathrm{~F}=10.7, \mathrm{p}=0.001)$ between the two environments. However, there was no significance at $0.05 \%$ probability for increment in BHD $(\mathrm{df}=1, \mathrm{~F}=0.52, \mathrm{p}=0.46)$ and basal area $(\mathrm{df}=1, \mathrm{~F}=0.53 ; \mathrm{p}=0.47)$.

\section{DISCUSSION}

The population of $A$. excelsa trees presented a zero-mortality rate between 2011 and 2014 . The absence of mortality was due to the high adaptation of these palm trees to the seasonally flooded environment (Parolin 2012). Attalea excelsa trees have morphological structures and physiological resources that enable them to survive in a seasonally flooded environment. In response to hypoxia, individuals produce aerenchyma and reduce the photosynthetic rate.

The diameter structure of the population revealed a reduction in the number of individuals in the first diameter classes. A similar pattern was found by Salm (2004) in the south-east of the Amazon for the Attalea maripa and Astrocaryum aculeatum palm trees. The dispersal process exerts great influence on the development and growth of young individuals. Primary dispersal of $A$. excels $a$ is barocoric, and as a result a large number of fruits fall around the matrix palm where they germinate, forming a dense seedling bank. This hinders the growth and development of young individuals, since seedlings established near the mother tree tend to have higher mortality rates due to the density-dependent effect and vulnerability to predators such as herbivores.

The lack of dispersant animals in the area may contribute to the low number of individuals in the initial diameter classes and to an increase in seed predation rate. Many fruits (still fresh) were found beneath the $A$. excelsa trees, without signs of claws or teeth of their effective dispersers such as agouti, pacas (Cuniculus paca) and peccaries (Pecari tajacu). These animals feed on the mesocarp of the fruit or bury the fruits to sate their hunger at another opportunity. This favours seed release for germination with greater ease.

The dispersant animals also have great influence in the spatial structure pattern and establishment of the vegetal species in their habitats. However, scarcity of dispersers in the study area makes it difficult to transport seeds at long distances. Nevertheless, some fruits are carried by the stream of the polymodal flood pulse at short distance because the fruits are heavy (average of $82.39 \mathrm{~g}$; Dantas et al. 2014), and do not float in the water. Hydrocoric dispersion favours the aggregate pattern of individuals, because the flooding of the forest transports the seeds and they are intercepted by the tree trunks, where they germinate in short distance between individuals (Figure 1f).

Habitat heterogeneity is also a determining factor in the spatial distribution of palm trees (Svenning 2001a, b). Topography has a great influence in the distribution of a community of palm trees in the Ecuadorian Amazon (Svenning 1999). This fact corroborates the results of this study, since the population parameters (density, basal area and diametric growth) are positively correlated with the lowest terrain and close to the main river where the flood is periodic. Areas that are permanently flooded and poor in nutrients limit the establishment of $A$. excelsa, suggesting a gradient. Carim et al. (2016) found no record of A. excelsa in the floristic composition of igapós (blackwater-flooded forests that are poor in nutrients) in Amapá State, but found high dominance of this species in the contiguous floodplain forest. Frangi and Lugo (1998) found a high density of palm trees along the river channel of the periodically flooded forest in Luquillo, Puerto Rico. Flood dynamics of a floodplain promotes the physical, chemical and biological processes of soils, influencing the quality and growth of the plant community (Piedade et al. 2010). High dominance of palm trees has been observed in lower levels of a floodplain forest on the island of Cambu in the State of Pará (Cattanio et al. 2002). This shows high adaptation of these plants to the periodically flooded environment.

The high diametric growth rate of $A$. excelsa may be correlated with the high amount of plant material deposited under the canopy. The accumulated plant material decomposes rapidly due to the humid environment the microclimate provided by the palm crown, favouring decomposing microorganisms. Nutrients released from the decomposition are readily absorbed by $A$. excelsa roots, favouring growth diameter of the species. In addition to soil, this species accumulates a large amount of 
dead plant biomass in the interpetiolar spaces that originate after leaf senescence, providing microhabitat for decomposing groups such as Psocoptera and Collembola (Negrelle 2015). These decomposing groups improve the nutritional status of A. excelsa. These spaces also house a rich seed bank (Corrêa et al. 2012). Diametric growth rate is relatively high in floodplain forest due to high content of nutrients available to the plants.

The population dynamic patterns of A. excelsa are reflections of the adaptation of the species to the polymodal flood cycle of the estuarine floodplain forest and the interactions between the local fauna. Individuals prefer to colonise periodically flooded soils. This shows that flooding is an important drive for diversification and adaptation of trees in Amazonian wetlands.

\section{ACKNOWLEDGEMENTS}

The authors would like to thank Embrapa Amapá, Conselho Nacional de Desenvolvimento Científico e Tecnológico (CNPq 142316/2016-4), Post-graduate Programme in Ecology (PPGEco/ INPA), Florestam project (Ecologia e manejo florestal para uso múltiplo de várzeas do estuário amazônico) and Kamukaia Project (Valorização dos produtos florestais não madeireiros na Amazônia 02.13.07.007.00.00).

\section{REFERENCES}

Alvares Ca, Stape JL, Sentelhas PC, Gonchalves Jlm \& SparoveK G. 2014. Köppen's climate classification map for Brazil. Meteorologische Zeitschrift 22: 711-728. https://doi.org/10.1127/0941-2948/2013/0507.

Balslev H, Kahn F, Millan B et al. 2011. Species diversity and growth forms in tropical American palm communities. The Botanical Review 77: 381-425. https://doi.org/10.1007/s12229-011-9084-x.

Carim MJV, Wittmann FK, Piedade MTF, Guimarães JRS \& Tostes LCL. 2016. Composition, diversity, and structure of tidal "Várzea" and "Igapó" floodplain forests in eastern Amazonia, Brazil. Brazilian Journal of Botany. 40: 115-124. https://doi.org/10.1007/ s40415-016-0315-6.

Cattanio JH, Anderson AB \& Carvalho MS. 2002. Floristic composition and topographic variation in a tidal floodplain forest in the Amazon Estuary. Revista Brasileira de Botânica 25: 419-430. https://doi. org/10.1590/S0100-84042002012000006.

CorrêA CE, Fischer E \& Santos FAM. 2012. Seed banks on Attalea phalerata (Arecaceae) stems in the Pantanal wetland, Brazil. Annals of Botany 109: 729-734. https://doi.org/10.1093/aob/mcr317.

Dantas AR. Lira-Guedes AC. Mustin K, Aparício WCS \& Guedes MC. 2016. Phenology of the multi-use tree species Carapa guianensis in a floodplain forest of the Amazon Estuary. Acta Botanica Brasilica 30: 618-627. https://doi.org/10.1590/0102$33062016 \mathrm{abb} 0282$.

Dantas AR, Marangon LC, Guedes MC, Feliciano AlP \& Lira-Guedes AC. 2017. Spatial distribution of a population of Pentaclethra macroloba (Willd.) Kuntze in a floodplain forest of the Amazon estuary. Revista Árvore 41: 1-11. https://doi.org/10.1590/180690882017000400006.

Dantas AR, Ribeiro GG, Guedes ACL \& Guedes MC. 2014. Produção de frutos de urucurizeiros, Attalea excelsa Mart. (Arecaceae), em floresta de várzea no Estuário do Rio Amazonas. Biota Amazônia 4: 108-114. https://doi.org/10.18561/2179-5746/ biotaamazonia.v4n4p108-114.

Diggle PJ. 2003. Statistical Analysis of Spatial Point Patterns. Eduard Arnold, London.

Eiserhardt WL, Svenning JC, Kissling WD \& Balslev H. 2011. Geographical ecology of the palms (Arecaceae): Determinants of diversity and distributions across spatial scales. Annals Botany 108: 1391-1416. https:// doi.org/10.1093/aob/mcr146.

Frangi JL \& Lugo AE. 1998. A flood plain palm forest in the Luquillo Mountains of Puerto Rico five years after Hurricane Hugo. Biotropica 30: 339-348. https:/ / doi. org/10.1111/j.1744-7429.1998.tb00069.x.

Freitas C, Meerow AW, Pintaud J et al. 2016. Phylogenetic analysis of Attalea (Arecaceae): insights into the historical biogeography of a recently diversified Neotropical plant group. Botanical Journal of the Linnean Society 182: 287-302. https://doi. org/10.1111/boj.12466.

ibGE (Instituto Brasileiro De Geografia E Estatística). 2012. Manual Técnico da Vegetação Brasileira : Sistema Fitogeográfico : Inventário das Formações Florestais e Campestres: Técnicas e Manejo de Coleções Botânicas : Procedimentos Para Mapeamentos. Second edition. IBGE, Rio de Janeiro.

INPE. 2017. TOPODATA: Banco de Dados Geomorfométricos do Brasil. http:/ /www.dsr.inpe.br/topodata/index. php. (Accessed 1.16.17).

Jardim MAG \& Mota CG. 2007. Biologia floral de Virola surinamensis (Rol.) Warb. (Myristicaceae). Revista Árvore 31: 1155-1162. https://doi.org/10.1590/ S0100-67622007000600020.

Junk WJ, Piedade MTF, Lourival R et al. 2014. Brazilian wetlands: their definition, delineation, and classification for research, sustainable management, and protection. Aquatic Conservation: Marine and Freshwater Ecosystems 24: 5-22. https://doi. org/10.1002/aqc.2386.

Kahn F \& Granville JJ. 1992. Palms in Forest Ecosystems of Amazonia, Ecological Studies. Springer Berlin Heidelberg, Berlin, Heidelberg. https://doi. org/10.1007/978-3-642-76852-1.

Klimas CA, Kainer KA \& Wadt LHO. 2007. Population structure of Carapa guianensis in two forest types in the southwestern Brazilian Amazon. Forest Ecology and Management 250: 256-265. https://doi. org/10.1016/j.foreco.2007.05.025.

Korning J \& Balslev H. 1994. Growth and mortality of trees in Amazonian tropical rain forest in Ecuador. Journal of Vegetation Science 5: 77-86. https://doi. org/10.2307/3235641. 
Martins RC, Filgueiras TDS \& Albuquerque UP. 2014. Use and diversity of palm (Arecaceae) resources in Central Western Brazil. The Scientific World Journal. 1: 1-14 https://doi.org/10.1155/2014/942043.

Nathan R \& Muller-Landau HC. 2000. Spatial patterns of seed dispersal, their determinants and consequences for recruitment. Trends in Ecology E Evolution 15: 278-285. https://doi.org/10.1016/S01695347(00)01874-7.

Negrelle RRB. 2015. Attalea phalerata Mart. ex Spreng.: aspectos botânicos, ecológicos, etnobotânicos e agronômicos. Ciência Florestal25: 1061-1066. https:// doi.org/10.5902/1980509820669.

PARolin P. 2012. Diversity of adaptations to flooding in trees of amazonian floodplains. Pesquisas Botânica 63: 7-28.

Piedade MTF, Ferreira CS, Wittmann AO, Buckeridge M \& Parolin P. 2010. Biochemistry of Amazonian floodplain trees. Pp 127-139 in Junk WJ et al. (eds) Amazonian Floodplain Forests, Amazonian Floodplain Forests: Ecophysiology, Biodiversity and Sustainable Management, Ecological Studies. Springer, Dordrecht.

Pintaud J. 2014. Una visión general de la taxonomía de Attalea (Arecaceae). Revista Peruana Biología 15: 55-63. https://doi.org/10.15381/rpb.v15i3.2968.

RIPLey BD. 1981. Spatial Statistics, Wiley Series in Probability and Statistics. John Wiley \& Sons, Inc., Hoboken. https:/ / doi.org/10.1002/0471725218.

Rowlingson B \& Diggle P. 2013. Splancs: spatial and spacetime point pattern analysis. Austria: $\mathrm{R}$ Development Core Team ( $\mathrm{R}$ package version 2.01-15).

SALM R. 2004. Stem density and growth of Attalea maripa and Astrocaryum aculeatum: implication for arborescent palms distribution across amazonian forests. Biota Neotropica 4: 1-11. https://doi.org/10.1590/S167606032004000100003.

Sheil D, Burslem DFRP \& Alder D. 1995. The Interpretation and misinterpretation of mortality rate measures. Journal of Ecology 83: 331-333. https://doi. org/10.2307/2261571.

Sheil D, Jennings S \& Savill P. 2000. Long-term permanent plot observations of vegetation dynamics in Budongo, a Ugandan rain forest. Journal of Tropical Ecology 16: 765-800. https://doi.org/10.1017/ S0266467400001723.
Shen Y, Santiago LS, Ma L, Lin GJ, Lian JY, Cao HL \& Ye WH. 2013. Forest dynamics of a subtropical monsoon forest in Dinghushan, China: recruitment, mortality and the pace of community change. Journal of Tropical Ecology 29: 131-145. https://doi.org/doi:10.1017/ S0266467413000059.

Smith N. 2015. Palms and People in the Amazon, Geobotany Studies. Springer International Publishing, Cham. https://doi.org/10.1007/978-3-319-05509-1.

Sturges HA. 1926. The choice of a class interval. Journal of the American Statistical Association 21: 65-66. https:/ / doi.org/10.1080/01621459.1926.10502161.

Svenning JC. 1999. Microhabitat specialization in a speciesrich palm rcommunity in Amazonian Ecuador. Jounal of Ecology 87: 55-65. https://doi.org/10.1046/j.13652745.1999.00329.x.

Svenning JC. 2001a. On the role of microenvironmental heterogeneity in the ecology and diversification of neotropical rain-forest palms (Arecaceae). The Botanical Review 67: 1-53. https:/ / doi.org/10.1007/ BF02857848.

Svenning JC. 2001b. Environmental heterogeneity, recruitment limitation and the mesoscale distribution of palms in a tropical montane rain forest (Maquipucuna, Ecuador). Journal of Tropical Ecology 17: 97-113. https://doi.org/10.1017/ S0266467401001067.

Wittmann F, Junk W \& Piedade M. 2004. The várzea forests in Amazonia: flooding and the highly dynamic geomorphology interact with natural forest succession. Forest Ecology and Management 196: 2-3. https://doi.org/10.1016/j.foreco.2004.02.060.

Wittmann F, Schöngart J \& Junk WJ. 2010. Phytogeography, species diversity, community structure and dynamics of Central Amazonian floodplain forests. Pp 61-102 in Junk WJ et al. (eds) Amazonian Floodplain Forests, Amazonian Floodplain Forests: Ecophysiology, Biodiversity and Sustainable Management, Ecological Studies. Springer Dordrecht.

Wittmann F, Schongart J, Montero JC et al. 2006. Tree species composition and diversity gradients in white-water forests across the Amazon Basin. Journal of Biogeography 33: 1334-1347. https://doi. org/10.1111/j.1365-2699.2006.01495.x. 